\title{
PERSEPSI, SIKAP, DAN STRATEGI KOPING KELUARGA MISKIN TERKAIT PROGRAM KONVERSI MINYAK TANAH KE LPG DI KOTA BOGOR
}

\author{
Poor Family's Perception, Attitude, and Coping Strategy Regarding on Cerosene \\ Convertion Program to LPG in Bogor City
}

\author{
EKA WULIDA LATIFAH ${ }^{1 *}$, HARTOYO $^{2}$, SUPRIHATIN GUHARDJA $^{2}$ \\ ${ }^{1}$ Staf Pengajar Departemen IImu Keluarga dan Konsumen, Fakultas Ekologi Manusia, \\ Institut Pertanian Bogor, Jalan Lingkar Kampus IPB Dramaga, \\ Bogor 16680 \\ ${ }^{2}$ Departemen IImu Keluarga dan Konsumen, Fakultas Ekologi Manusia, Institut Pertanian \\ Bogor, Kampus Dramaga, Bogor 16680
}

\begin{abstract}
Nowadays, the increasing energy demand is related to the growth of economy activities and the growth of population. The increasing of Indonesian population over years and the increasing of variaty of economy activities and its output within society causing increasing demand of energy are being something that cannot be avoided. In addition, Indonesia's dependable to the energy had increased the demand of energy. Meanwhile, energy reserve is running low both in Indonesia and the world. Energy crisis that has happened this time triggers various parties to do several new experiments, especially that concern to public policy. One step by the government to overcome this kerosene crisis is by the conversion from kerosene to LPG. The conversion from Kerosene to LPG program is one effort that has been done by the government to decrease the dependency society towards kerosene. The aim of this study was to analyze the poor family respons to cerosene convertion program to LPG in Sindang Barang Village and Cikaret Village, Bogor City. The Study implemented cross sectional and survey method through the process of purposive sampling procedures. One of the criteria in choosing the study location was that the location had the highest quantity which received cerosene convertion program to LPG. The samples of the family were chosen randomly from the chosen location. The total samples were 60 families. The study used descriptive analysis that contains secondary data, literature study, and primary data (from questionnaire). Beside that, Pearson correlation dan linear regression tests were also used to analyze the data. The result found out that $18,33 \%$ of the samples were actually not really received the program. Around 60\% of the family had monthly expense per capita of Rp 222.123,00 which was below the poverty line. Kerosene conversion program is proved to decrease family expenditure of kerosene to be LPG user. This is showed by expenditure depreciation existence after conversion program is carried out around $R p$ 66.400,00 every month (used kerosene prices before program) and $R p$ 202.350,00 every month (used kerosene prices after program). But for samples that convert from to $L P G$, the expenditure rise from $R p$ 10.250,00 every month become $R p 44.700,00$ every month. The study also found that generally, most of LPG users ask money to the extended family and cook in their family when they have not money to buy LPG refill. The Government wished can give the sosialization in a good way to use LPG, not only give the information that $L P G$ is safe, clean, cheap, and good for environment. Besides that, it needs to empower society in order to prepare money to buy LPG refill.
\end{abstract}

Key words: convertion, coping strategy, poor family

\section{PENDAHULUAN}

Energi memainkan peranan penting dalam semua aspek kehidupan manusia.
Peningkatan kebutuhan energi mempunyai keterkaitan erat dengan bertambahnya jumlah penduduk. Remi (2008) menyatakan bahwa jumlah penduduk Indonesia dalam 
waktu 25 tahun mendatang diperkirakan akan terus meningkat yaitu dari 205,8 juta pada tahun 2000 menjadi 273,7 juta pada tahun 2025, sehingga kebutuhan energi di masa mendatang diperkirakan akan meningkat pula.

Bahan bakar minyak (BBM) merupakan salah satu jenis energi yang banyak digunakan di Indonesia. Cadangan BBM di Indonesia semakin menipis sehingga untuk memenuhi kebutuhan masyarakat, pemerintah harus mengimpor BBM. Namun, salah satu permasalahan yang dialami oleh pemerintah ialah tingginya harga minyak dunia yang mendekati angka US\$ 100 per barel pada tahun 2008 sehingga memerlukan devisa yang cukup untuk mensubsidi BBM. Kondisi ini ternyata berakibat pada pengurangan cadangan devisa negara dan peningkatan biaya subsidi minyak dan pada gilirannya dapat membebani APBN dari tahun ke tahun.

Minyak tanah merupakan salah satu jenis BBM yang biasa digunakan pada skala rumah tangga. Indonesia merupakan satusatunya negara yang menggunakan minyak tanah sebagai sumber energi pada skala rumah tangga. Di negara lain, minyak tanah diolah menjadi avtur sehingga memiliki nilai tambah yang lebih tinggi sebagai bahan bakar pesawat terbang (Anonim 2008a). Oleh karena itu, penggunaan minyak tanah pada skala rumah tangga di Indonesia dianggap tidak efektif dan efisien.

Untuk mengatasi permasalahan tersebut, pemerintah menetapkan program konversi minyak tanah ke LPG. Hasil perhitungan yang dilakukan oleh Departemen Energi dan Sumberdaya Mineral menunjukkan bahwa penerapan kebijakan ini dapat mengurangi subsidi yang harus dikeluarkan oleh Pemerintah, sebesar Rp 20,12 triliyun per tahun dengan asumsi seluruh minyak tanah telah dikonversi ke elpiji. Program konversi seluruh minyak tanah bersubsidi ke LPG ini direncanakan akan selesai dalam jangka waktu 5 tahun (dari tahun 2007 hingga tahun 2012).

Program konversi ini dilakukan melalui pembagian paket LPG $3 \mathrm{~kg}$ beserta tabung, kompor, regulator, dan selang secara gratis kepada keluarga miskin yang jumlahnya mencapai 41,1 juta jiwa (LIPI 2008) dan 170.000 jiwa di Kota Bogor (BPS 2009). Penggunaan LPG yang dianggap sebagai teknologi yang baru bagi masyarakat miskin ini memerlukan waktu untuk dapat diterima sebagai pengganti bahan bakar yang sudah biasa digunakan. Bagi sejumlah masyarakat miskin dengan segala keterbatasannya, dimungkinkan teknologi penggunaan LPG merupakan sumber stres tersendiri. Sebagian besar dari 41.000 keluarga miskin di kota Bogor masih enggan menggunakan tabung gas dan tetap menggunakan minyak tanah sebagai bahan bakar utama kebutuhan dapurnya (Anonim 2008b). Hal ini berkaitan dengan ketakutan masyarakat terhadap LPG dikarenakan banyaknya kasus kompor gas yang meledak. Di satu sisi, masyarakat dituntut untuk menggunakan LPG, namun di sisi lain, masyarakat juga memiliki banyak keterbatasan untuk beradaptasi dengan penggunaan LPG ini.

Penelitian mengenai keluarga miskin penerima program konversi minyak tanah ke gas di Kota Bogor ini dianggap perlu untuk dilakukan agar Pemerintah Kota Bogor dapat mengetahui bagaimana respon masyarakat miskin penerima bantuan kompor gas dan LPG terhadap teknologi yang dianggap baru oleh mereka. Hal ini penting dilakukan agar program ini dapat mencapai tujuan sesuai dengan yang diharapkan, yakni seluruh masyarakat, khususnya masyarakat miskin mau menerima LPG dengan kesadaran penuh.

Penelitian ini bertujuan untuk: (1) mengidentifikasi karakteristik keluarga penerima program konversi minyak tanah ke LPG; (2) mengidentifikasi persepsi dan sikap ibu rumah tangga terhadap LPG di Kota Bogor; (3) menghitung perubahan pengeluaran bahan bakar keluarga pascaprogram konversi minyak tanah ke LPG; (4) mengidentifikasi strategi koping keluarga ibu rumah tangga terhadap masalah-masalah yang timbul dalam penggunaan LPG; (5) menganalisis hubungan antara karakteristik keluarga ibu rumah tangga dengan persepsi dan sikap ibu rumah tangga terhadap LPG; dan (6) menganalisis faktor yang mempengaruhi strategi koping keluarga ibu rumah tangga terhadap ketidakmampuan membeli isi ulang LPG.

\section{METODE}

\section{Desain, Lokasi, dan Waktu}

Desain penelitian ini adalah cross sectional study. Penelitian dilakukan di Kelurahan Sindang Barang, Kecamatan Bogor Barat dan Kelurahan Cikaret, Kecamatan Bogor Selatan. Pelaksanaan pengambilan data dilakukan selama 5 
minggu, dari awal bulan Mei 2009 hingga awal bulan Juni 2009.

\section{Teknik Penarikan Contoh}

Populasi penelitian ini adalah keluarga miskin perkotaan dengan kerangka ibu rumah tangga keluarga miskin penerima bantuan program konversi minyak tanah ke LPG. Ibu rumah tangga berasal dari keluarga miskin penerima program konversi yang tinggal di RW 04 Kelurahan Sindang Barang dan RW 08 Kelurahan Cikaret. Ibu rumah tangga dalam penelitian ini adalah 60 orang ibu rumah tangga yang menerima bantuan program konversi minyak tanah ke LPG. Dari kedua RW tersebut kemudian dipilih masingmasing sebanyak 30 ibu rumah tangga sebagai syarat minimal uji statistik dari 183 kepala keluarga di RW 04 Kelurahan Sindang Barang dan 128 kepala keluarga di RW 08 Kelurahan Cikaret dengan menggunakan metode penarikan ibu rumah tangga secara acak sederhana. Melalui teknik ini kemudian diperoleh sebanyak 60 ibu rumah tangga dari kedua wilayah. Namun, peng-ukuran strategi koping pada penelitian ini hanya dilakukan pada ibu rumah tangga yang menggunakan LPG ( $\mathrm{n}=$ 49).

\section{Jenis dan Teknik Pengumpulan Data}

Data yang dikumpulkan pada penelitian ini meliputi data primer dan data sekunder. Data primer meliputi karakteristik keluarga (besar keluarga, pendapatan, umur, pekerjaan, dan pendidikan kepala keluarga), karakteristik ibu rumah tangga (umur, pekerjaan, dan pendidikan), persepsi, persepsi terhadap waktu, sikap, perubahan pengeluaran rumah tangga, dan strategi koping. Data sekunder diperoleh dari instansi terkait meliputi gambaran umum wilayah, potensi wilayah, data keluarga miskin, dan data pendistribusian LPG. Metode pengumpulan data dilakukan secara survei melalui wawancara dengan menggunakan kuesioner.

\section{Pengolahan dan Analisis Data}

Data yang telah terkumpul diolah dengan menggunakan program Microsoft Excel dan SPSS for Windows. Analisis data penelitian ini dilakukan dengan: (1) Uji korelasi Pearson yang digunakan untuk menganalisis hubungan antara variabelvariabel: (a) karakteristik ibu rumah tangga dan keluarga (umur, pendidikan, pekerjaan, besar keluarga, pendapatan dan pengeluaran per kapita) dengan persepsi terhadap
LPG, (b) karakteristik ibu rumah tangga dan keluarga (umur, pendidikan, pekerjaan, besar keluarga, pendapatan, dan pengeluaran per kapita) dengan sikap terhadap LPG; (2) Uji regresi linear berganda yang dilakukan untuk menganalisis pengaruh karakteristik ibu rumah tangga (umur, tingkat pendidikan, dan status pekerjaan) dan karakteristik keluarga (pekerjaan suami, pendidikan suami, jumlah anggota keluarga, dan pendapatan per kapita), persepsi, dan sikap terhadap strategi koping ibu rumah tangga ketika tidak mampu membeli isi ulang LPG.

\section{HASIL DAN PEMBAHASAN}

\section{Karakteristik Keluarga Ibu Rumah Tangga}

Usia. Usia suami berkisar antara 27 hingga 80 tahun dengan rata-rata usia suami secara keseluruhan adalah 46,22 tahun. Sebanyak $44,90 \%$ diantaranya berusia 41 65 tahun, sedangkan yang berusia di bawah 41 tahun sebanyak $40,82 \%$. Usia istri berkisar antara 23 sampai 85 tahun dengan rata-rata 44 tahun, artinya istri termasuk dalam kategori dewasa madya. Persentase terbesar istri termasuk dalam kategori dewasa muda $(48,33 \%)$.

Tipe dan Besar Keluarga. Sebanyak $60 \%$ keluarga ibu rumah tangga adalah keluarga inti, sementara sebanyak $40 \%$ keluarga ibu rumah tangga merupakan keluarga luas. Anggota keluarga ibu rumah tangga berkisar antara 3 sampai 13 orang dengan rata-rata 5,7 orang, artinya rata-rata ibu rumah tangga termasuk dalam kategori keluarga sedang. Sebanyak 48,33\% ibu rumah tangga termasuk dalam kategori keluarga sedang.

Pendidikan. Tingkat pendidikan suami tersebar pada berbagai tingkat pendidikan yaitu tidak sekolah, tidak tamat SD, tamat SD, tamat SMP, dan tamat SMA. Tidak ada ibu rumah tangga yang tingkat pendidikannya sampai dengan perguruan tinggi atau akademi. Persentase terbesar tingkat pendidikan suami ialah tamat SD (32,65\%). Sama halnya dengan pendidikan suami, pendidikan sepertiga istri juga tergolong masih rendah. Persentase terbesar tingkat pendidikan ibu rumah tangga secara umum ialah tamat SD $(38,3 \%)$.

Pekerjaan. Pekerjaan utama suami adalah sebagai buruh, sehingga pendapatan terbesar diperoleh dari kegiatannya sebagai buruh. Jumlah suami yang tidak bekerja ternyata mencapai angka 14,29\%. Hal ini menunjukkan bahwa angka pengangguran 
pada masyarakat miskin perkotaan cukup besar pada laki-laki yang sudah berkeluarga. Secara umum, proporsi ibu yang bekerja (45\%) lebih sedikit dibandingkan dengan ibu yang tidak bekerja (55\%).

Pendapatan. Keluarga ibu rumah tangga memiliki rata-rata pendapatan sebesar Rp 106.497,00. Pendapatan terkecil dan terbesar yakni sebesar Rp 10.000,00 per kapita per bulan dan Rp 300.000,00 per kapita per bulan. Hal ini menunjukkan bahwa rata-rata pendapatan keluarga per kapita per bulan di kedua wilayah masih berada di bawah garis kemiskinan, yakni batas dimana seseorang dapat memenuhi kebutuhan makanan dan nonmakanan yaitu sebesar Rp 222.123,00 (Dinas Kesehatan 2008).

Pengeluaran. Hasil penelitian menunjukkan bahwa keluarga ibu rumah tangga memiliki rata-rata pengeluaran sebesar Rp 205.346,00. Pengeluaran terkecil ibu rumah tangga ialah sebesar $\mathrm{Rp} 67.722,00$ per kapita per bulan dan pengeluaran terbesar ibu rumah tangga ialah sebesar Rp 470.833,00 per kapita per bulan.

Berbeda dengan hasil penelitian sebelumnya, berdasarkan data pengeluaran keluarga, mengacu kepada batas kemiskinan di Kota Bogor, ternyata terdapat $60 \%$ keluarga ibu rumah tangga yang termasuk ke dalam kategori keluarga miskin dan 40\% lainnya tidak termasuk ke dalam kategori keluarga miskin.

\section{Penggunaan Energi dalam Rumah Tangga}

Sebelum program konversi minyak tanah ke LPG berlangsung, sebanyak 55\% keluarga ibu rumah tangga menggunakan kayu bakar dan 45\% lainnya menggunakan minyak tanah sebagai bahan bakar. Setelah program konversi minyak tanah ke LPG berlangsung, terdapat sebanyak 81,67\% keluarga ibu rumah tangga menggunakan LPG dan masih ada 11 keluarga ibu rumah tangga $(18,33 \%)$ yang tidak menggunakan LPG. Keluarga ibu rumah tangga yang tidak menggunakan LPG, saat ini menggunakan kayu bakar $(8,3 \%)$ dan minyak tanah $(10 \%)$ untuk memasak walaupun sebenarnya seluruh ibu rumah tangga diberikan bantuan kompor gas dan LPG gratis.

Ada beberapa alasan yang menyebabkan keluarga ibu rumah tangga tidak menggunakan LPG. Sebanyak 54,55\% keluarga ibu rumah tangga merasa takut sehingga penggunaan kayu bakar ataupun minyak tanah dianggap lebih aman bagi mereka. Sebagian kecil diantaranya tidak mengguna- kan LPG karena memang tidak bisa menggunakannya, harga isi ulang LPG yang cukup mahal, dan terpaksa menjual tabung LPG untuk membayar hutang keluarga.

Berdasarkan hasil penelitian terhadap keluarga ibu rumah tangga yang beralih dari minyak tanah ke LPG, terjadi penurunan pengeluaran setelah program konversi dilaksanakan. Pengeluaran keluarga untuk bahan bakar berkurang dari Rp 111.250,00 per bulan menjadi Rp 44.850,00 per bulan atau per $\mathrm{KK}$ melakukan penghematan Rp 66.400,00 per bulan dengan harga minyak tanah sebelum program konversi. Sementara, setelah program konversi berlangsung, minyak tanah sudah tidak disubsidi lagi sehingga harga minyak tanah meningkat menjadi Rp 8.000,00 per liter.

Berbeda dengan keluarga ibu rumah tangga yang beralih dari kayu bakar ke LPG, pengeluaran rata-rata untuk bahan bakar pada ibu rumah tangga mengalami peningkatan yakni dari Rp 10.250,00 per bulan menjadi $\mathrm{Rp} 44.700,00$ per bulan atau mengalami peningkatan biaya sebesar Rp 34.450,00 per bulan. Ini berarti bahwa penghematan pengeluaran keluarga untuk bahan bakar setelah program konversi minyak tanah ke LPG berlangsung hanya dapat dilakukan oleh ibu rumah tangga yang sebelumnya menggunakan LPG. Sementara pada keluarga ibu rumah tangga yang sebelumnya menggunakan kayu bakar, pengeluaran keluarga untuk bahan bakar justru menjadi lebih besar.

\section{Persepsi dan Sikap}

Proporsi terbesar ibu rumah tangga $(71,67 \%)$ termasuk ke dalam kategori persepsi yang baik terhadap LPG. Hal ini mungkin disebabkan karena LPG memiliki karakteristik produk yang diinginkan oleh masyarakat. Pertama, LPG merupakan bahan yang dibutuhkan oleh masyarakat. Kedua, LPG memiliki beberapa kelebihan dibandingkan dengan minyak tanah. Ketiga, kemungkinan tidak ada alternatif bahan bakar lain yang tersedia sehingga masyarakat menggunakan LPG. Ketiga hal tersebut mencukupi untuk diterimanya suatu inovasi teknologi dan ini sesuai dengan teori adopsi inovasi menurut Lionberger (1960).

Namun, masih terdapat hampir sepertiga ibu rumah tangga (28,33\%) yang memiliki persepsi yang kurang baik terhadap LPG. Seperti yang dikatakan oleh Rogers dan Shoemaker (1971) bahwa tidak setiap orang mengadopsi inovasi pada tingkat yang 
sama. Ada orang yang melakukannya dalam waktu singkat tetapi ada yang melakukannya setelah waktu bertahun-tahun. Harga LPG yang masih kurang terjangkau oleh masyarakat miskin serta sosialisasi program yang belum maksimal diduga sebagai faktor yang cukup mempengaruhi persepsi dan penerimaan ibu rumah tangga terhadap keberadaan LPG.

Berdasarkan analisis multiatribut Fishbein, minyak tanah dan LPG memiliki kelebihan. Pada atribut harga pembelian isi ulang yang terjangkau, secara umum ibu rumah tangga lebih menyukai harga pembelian isi ulang LPG meskipun harga keduanya termasuk kategori mahal bagi ibu rumah tangga. Hal ini dirasakan belum sesuai dengan teori Van den Ban (1996) yang menyatakan bahwa produk baru harus memiliki keuntungan relatif yang tinggi bagi pengguna. Selain itu, ibu rumah tangga lebih merasakan bahwa LPG mudah diperoleh, sementara minyak tanah sangat sulit untuk ditemukan di sejumlah warung dan toko terdekat.

Berdasarkan atribut kepraktisan, kebersihan peralatan masak, kecepatan waktu memasak, kemudahan menggunakan, keramahan terhadap lingkungan, dan kemudahan pemeliharaan, LPG lebih disukai dibandingkan dengan minyak tanah. Semakin mudah teknologi baru dipraktekkan, maka semakin cepat pula proses adopsi inovasi yang dilakukan. Oleh karena itu, agar proses adopsi dapat berjalan dengan cepat, maka penyajian inovasi harus lebih sedehana (Soekartawi 1988). Dengan demikian, kompleksitas suatu inovasi mempunyai pengaruh yang besar terhadap percepatan adopsi inovasi. Maka dari itu, perlu dilakukan peragaan dan pelatihan secara partisipatif.

Namun, di sisi lain, harga pembelian peralatan minyak tanah lebih disukai dibandingkan dengan LPG. Bentuk kemasan LPG lebih disukai dibandingkan dengan minyak tanah, namun untuk bentuk produk, minyak tanah (cair) lebih disukai dibandingkan dengan bentuk kemasan LPG (tabung) dan bentuk LPG (gas) yang diperkirakan lebih berat dan tidak terlihat.

Dari aspek kenyamanan dan keamanan, minyak tanah ternyata lebih disukai dibandingkan dengan LPG. Selain itu, minyak tanah dianggap memiliki kegunaan yang lebih banyak dibandingkan dengan LPG karena minyak tanah dapat digunakan untuk keperluan selain memasak, yakni untuk lampu tempel, membakar sampah, dan sebagai obat. Sesuai dengan teori adopsi yang menyatakan bahwa suatu produk baru harus sesuai dengan nilai-nilai, pengalaman dan kebutuhan masyarakat sasaran maka kebiasaan masyarakat untuk menggunakan LPG sebagai bahan bakar masih cukup sulit untuk dilakukan karena mereka sudah terbiasa menggunakan minyak tanah.

Peralatan yang digunakan ketika menggunakan minyak tanah dirasakan lebih mudah dibandingkan dengan LPG karena ibu rumah tangga dapat membetulkan sendiri kompor minyak tanah jika terjadi kerusakan ataupun kebocoran. Sementara LPG lebih rumit untuk diperbaiki karena masyarakat masih belum dapat memperbaiki sendiri peralatan dan perlengkapan pada LPG jika terjadi kerusakan sehingga menurut teori adopsi inovasi LPG masih belum memenuhi kriteria sebagai produk baru yang dapat diterima oleh masyarakat sasaran. Hal ini berkaitan dengan pelayanan pasca penjualan dari LPG yang dirasakan masih kurang keberadaannya. Keberadaan pelayanan pascajual diperlukan untuk membantu masyarakat yang mengalami kesulitan dalam memperbaiki kerusakan atau kebocoran pada LPG.

\section{Strategi Koping Keluarga \\ Variabel strategi koping dalam} penelitian ini dikhususkan bagi ibu rumah tangga yang saat ini menggunakan LPG sehingga pada pembahasan selanjutnya, hanya ibu rumah tangga pengguna LPG yang dianalisis. Lazarus (1991) dalam Goldsmith (1996) mendefinisikan koping sebagai suatu hal yang merujuk pada adaptasi individu terhadap kondisi yang relatif sulit dan tidak menyenangkan.

Strategi koping dapat diartikan sebagai upaya atau cara yang dilakukan individu atau rumah tangga dalam menghadapi dan mengatasi situasi atau keadaan yang tidak menguntungkan. Suatu kondisi dimana keluarga miskin menghadapi permasalahan pada LPG dan ketidakmampuan membeli isi ulang LPG dapat menjadi suatu stressor sehingga menuntut keluarga untuk melakukan berbagai perilaku dan tindakan untuk mengatasi permasalahan tersebut. Pada penelitian ini, ibu rumah tangga dapat melakukan lebih dari satu perilaku atau tindakan dalam mengatasi berbagai permasalahan pada LPG.

Strategi Koping terhadap Permasalahan Pemakaian LPG. Hasil 
penelitian menunjukkan bahwa ibu rumah tangga yang masih menggunakan LPG pernah mengalami kerusakan LPG $(55,1 \%)$. Kerusakan LPG pada penggunanya dapat disebabkan oleh kurangnya sosialisasi mengenai penggunaan dan perawatan LPG. Rendahnya pengetahuan ibu rumah tangga mengenai LPG juga mengakibatkan risiko kerusakan dan kesulitan penanganan LPG.

Strategi koping yang paling banyak dilakukan oleh ibu rumah tangga ketika mengalami kerusakan pada LPG ialah dengan meminta bantuan tetangga $(40,7 \%)$ dan mengganti peralatan yang rusak dengan yang baru $(44,4 \%)$. Meminta bantuan kepada tetangga biasanya dilakukan oleh ibu rumah tangga karena tetangga dianggap sebagai pihak pertama yang dapat memberikan bantuan dan merupakan orang terdekat yang dapat membantu kesulitan yang dialami oleh keluarga. Tindakan keluarga dengan mengganti peralatan yang rusak dengan yang baru dilakukan karena masih banyak masyarakat yang takut untuk memperbaiki kompor, selang ataupun regulator yang rusak sehingga lebih memilih untuk menggantinya dengan peralatan yang baru.

Strategi koping dengan meminta bantuan tetangga lebih banyak dilakukan pada ibu rumah tangga yang tinggal di Sindang Barang (29,6\%) dibandingkan dengan ibu rumah tangga yang tinggal di Cikaret (11,1\%). Begitu pula dengan tindakan mengganti peralatan yang rusak dengan yang baru, ibu rumah tangga di Sindang Barang lebih banyak melakukan hal tersebut $(25,9 \%)$ dibandingkan dengan ibu rumah tangga di Cikaret (18,5\%).

Berdasarkan hasil wawancara secara kualitatif, ibu rumah tangga di Sindang Barang yang mencoba memperbaiki sendiri peralatan dan perlengkapan LPG yang rusak lebih banyak $(22,22 \%)$ dibandingkan dengan ibu rumah tangga di Cikaret $(7,4 \%)$. Hanya sebagian kecil diantaranya yang meminta bantuan saudara atau suami, menggunakan jasa sales regulator, diam saja, ikut memasak di tempat saudara, dan mencoba bersabar ketika mereka mengalami kerusakan atau kebocoran pada LPG. Jasa sales regulator merupakan fenomena yang cukup banyak di masyarakat mengingat penanganan permasalahan LPG hanya bisa dilakukan oleh orang yang mengerti tentang LPG.

Hasil wawancara menunjukkan bahwa sebanyak $44,9 \%$ ibu rumah tangga tidak pernah mengalami kerusakan LPG. Ibu rumah tangga dapat menjaga peralatan dan perlengkapan LPG dengan baik. Berdasarkan hasil wawancara secara kualitatif, ibu rumah tangga di kedua wilayah yang tidak pernah mengalami kerusakan LPG memang rajin membersihkan kompor gas (100\%) sehingga tidak ada di antara mereka yang mengalami kerusakan LPG. Ada sebagian kecil diantaranya yang menservis sendiri peralatan dan perlengkapan LPG, membersihkan kabel atau selang pada LPG, membeli pengaman, dan rajin mengecek kondisi selang LPG.

\section{Strategi Koping terhadap} Ketidakmampuan Membeli Isi Ulang LPG. Hasil penelitian menunjukkan bahwa sebagian besar pengguna LPG $(91,84 \%)$ pernah mengalami ketidakmampuan dalam membeli LPG. Ketidakmampuan dalam membeli LPG dapat disebabkan karena tidak adanya biaya untuk membeli LPG dan kesulitan pengguna LPG untuk membeli bahan bakar dengan harga yang cukup mahal. Hal ini juga diduga berkaitan dengan permasalahan alokasi dana yang digunakan untuk membeli tabung $3 \mathrm{~kg}$ dengan kisaran harga Rp 13.500,00 hingga Rp 17.000,00. Padahal sebelumnya masyarakat bisa membeli minyak tanah dengan kisaran harga sekitar Rp 2.500,00 hingga Rp 4.500,00. Kondisi ini menyebabkan masyarakat harus mengalokasikan dana yang besar untuk membeli isi ulang LPG. Harga tabung yang cukup mahal akan membuat masyarakat miskin mengalami kesulitan. Padahal, suatu kebijakan sosial seharusnya dibuat oleh Pemerintah dengan memperhatikan kelompok yang rentan seperti masyarakat miskin. Kondisi inilah yang mendorong keluarga untuk melakukan berbagai cara untuk mengatasi kerusakan dan ketidakmampuan dalam membeli LPG.

Strategi koping dalam penelitian ini merupakan salah satu bentuk problemfocused coping dimana ibu rumah tangga memecahkan masalah yang akan dilakukan dengan menentukan masalah, menciptakan pemecahan alternatif, mempertimbangkan alternatif terkait biaya dan manfaat, memilih salah satu alternatif yang dipilih (Lazarus 1976 dalam Agustina 2006).

Berdasarkan hasil penelitian, strategi koping yang paling banyak dilakukan oleh ibu rumah tangga ketika tidak mampu membeli LPG ialah meminta uang pada keluarga dekat $(82,22 \%)$ dan ikut memasak di tempat saudara $(77,78 \%)$. Meminta uang kepada keluarga dekat merupakan salah 
satu alternatif pemecahan masalah yang dilakukan ibu rumah tangga karena hal ini keluarga dekat merupakan salah satu sumberdaya lingkungan yang dapat dimanfaatkan ketika keluarga memiliki permasalahan. Ikut memasak di tempat saudara biasanya dilakukan oleh ibu rumah tangga karena saudara dianggap sebagai pihak pertama yang dapat memberikan bantuan dan merupakan orang terdekat yang dapat membantu kesulitan yang dialami oleh suatu keluarga.

Tindakan keluarga dengan menggunakan kayu bakar merupakan salah satu alternatif yang dapat dilakukan karena biaya yang dibutuhkan memang tidak terlalu mahal. Keluarga dapat memperoleh kayu bakar dengan memanfaatkan kayu sisa bangunan atau menebang pohon di sekitar rumahnya. Strategi koping dengan meminjam uang kepada keluarga dekat lebih banyak dilakukan pada ibu rumah tangga yang tinggal di Cikaret (90\%) dibandingkan dengan ibu rumah tangga yang tinggal di Sindang Barang (76\%). Sementara, strategi koping yang dengan ikut memasak di tempat saudara lebih banyak dilakukan oleh ibu rumah tangga yang tinggal di Sindang Barang (80\%) dibandingkan dengan ibu rumah tangga di Cikaret (75\%).

\section{Hubungan antar Variabel}

Hasil penelitian menunjukkan bahwa ibu rumah tangga yang memiliki pendapatan dibawah Rp 100.000,00 justru lebih banyak memiliki persepsi yang cukup baik terhadap LPG dibandingkan dengan yang lainnya. Berdasarkan hasil uji korelasi Pearson, pendapatan per kapita keluarga memiliki hubungan yang positif dengan persepsi ibu rumah tangga terhadap LPG $(p=0,039$; $r=0,267)$. Hal ini berarti bahwa semakin tinggi tingkat pendapatan ibu rumah tangga, maka persepsi ibu rumah tangga terhadap LPG semakin baik. Menurut Kotler (2000), persepsi dipengaruhi oleh faktor internal yang terdiri dari kecerdasan, minat, emosi, pendidikan, pendapatan, kapasitas alat indera, dan jenis kelamin. Hal ini menunjukkan bahwa pendapatan memang mempengaruhi bagaimana seseorang berpikir dan mengamati manfaat dan keberadaan LPG.

Hasil penelitian menunjukkan bahwa ibu rumah tangga yang tamat SD lebih banyak memiliki sikap yang cukup baik terhadap LPG dibandingkan dengan tingkat pendidikan lainnya. Hubungan antara pendidikan ibu rumah tangga dengan sikap ibu rumah tangga terhadap LPG diuji dengan meng- gunakan uji korelasi Pearson. Hasil uji korelasi menunjukkan adanya hubungan yang positif antara pendidikan ibu rumah tangga dengan sikap ibu rumah tangga terhadap LPG $(p=0,024 ; r=0,292)$. Hal ini berarti bahwa semakin lama ibu rumah tangga bersekolah, maka sikap ibu rumah tangga terhadap LPG semakin baik. Seseorang yang lebih banyak berpikir dan memiliki wawasan yang lebih luas biasanya lebih mudah menerima keberadaan sesuatu yang dianggap baru atau berbeda dari biasanya sesuai dengan pernyataan Pearlin dan Scholer (1976) dalam Furi (2006) bahwa individu dengan pendidikan yang tinggi umumnya bersikap optimis.

Hasil penelitian menunjukkan bahwa ibu rumah tangga yang memiliki pendapatan dibawah Rp 222.123,00 justru lebih banyak memiliki sikap yang cukup baik terhadap LPG dibandingkan dengan yang lainnya. Hubungan antara pendapatan ibu rumah tangga dengan sikap ibu rumah tangga terhadap LPG diuji dengan menggunakan uji korelasi Pearson. Hasil uji korelasi menunjukkan adanya hubungan yang positif antara pendapatan ibu rumah tangga dengan sikap ibu rumah tangga terhadap LPG $(p=0,020$; $r=0,300)$. Hal ini berarti bahwa semakin tinggi tingkat pendapatan ibu rumah tangga, maka sikap ibu rumah tangga terhadap LPG semakin baik. Ibu rumah tangga yang memiliki pendapatan yang lebih besar lebih cenderung menilai LPG sebagai produk yang baik karena daya belinya terhadap LPG cukup tinggi. Kemampuannya untuk membeli LPG mendorongnya untuk memiliki sikap yang baik terhadap LPG.

\section{Faktor-Faktor yang Mempengaruhi Strategi Koping Keluarga}

Hasil uji regresi menunjukkan bahwa usia, lama pendidikan, pekerjaan, jenis keluarga, jumlah anggota keluarga, pendapatan per kapita keluarga, persepsi, dan sikap terhadap LPG memiliki pengaruh sebesar 6,2\% terhadap strategi koping ibu rumah tangga terhadap ketidakmampuan membeli isi ulang LPG, selebihnya dijelaskan oleh variabel-variabel yang lain di luar model tersebut. Hal ini berarti bahwa banyak faktor lain yang dapat mempengaruhi perilaku strategi koping ibu rumah tangga terhadap ketidakmampuan membeli isi ulang LPG. Dari model regresi linier berganda, hanya variabel usia $(p=0,077)$ dan lama pendidikan $(p=0,070)$ yang memiliki pengaruh nyata terhadap strategi koping ibu rumah tangga. 
Diantara kedua variabel tersebut, variabel usia memiliki pengaruh yang besar terhadap jumlah strategi koping yang dilakukan oleh ibu rumah tangga ketika tidak mampu membeli LPG karena memiliki nilai beta tertinggi, yakni sebesar 0,341 .

Lazarus dan Folkman (1984) menyatakan bahwa setiap orang akan bereaksi terhadap situasi yang sama dalam bentuk yang berbeda-beda dan dengan beberapa cara. Adapun faktor-faktor yang mempengaruhi strategi koping antara lain: jenis kelamin, umur dan perkembangan, tingkat pendidikan, stres dan kecemasan, situasi, persepsi, intelektual, kondisi kesehatan, serta situasi sosial ekonomi.

Variabel usia pada Tabel 1 memiliki nilai $b=0,033$, artinya setiap kenaikan usia ibu rumah tangga sebanyak 1 tahun maka akan meningkatkan jumlah strategi koping yang dilakukan sebanyak 0,033 cara. Hal ini menunjukkan bahwa semakin bertambah usia seseorang, maka akan semakin banyak alternatif cara yang dilakukan untuk menghadapi permasalahan yang dialaminya. Hal ini berkaitan dengan pengalaman hidup seseorang yang semakin banyak dengan semakin bertambahnya usia. Lazarus dan Folkman (1984) menyatakan bahwa salah satu faktor yang mempengaruhi strategi koping seseorang adalah pengalamannya dalam menghadapi masalah. Seseorang yang memiliki banyak pengalaman dalam menghadapi berbagai macam permasalahan akan memiliki banyak cara dan strategi dalam kondisi stres sekalipun.

Lama pendidikan juga memiliki pengaruh yang nyata terhadap strategi koping yang dilakukan oleh ibu rumah tangga. Berdasarkan hasil uji regresi, setiap terjadi peningkatan lama pendidikan ibu rumah tangga sebanyak satu tahun akan meningkatkan jumlah strategi koping yang dilakukan sebanyak 0,120 cara. Hal ini berarti semakin lama seseorang duduk di bangku sekolah, maka akan semakin banyak cara yang ia lakukan untuk menghadapi permasalahan yang dihadapi. Hal ini berkaitan dengan semakin banyaknya ilmu pengetahuan yang diperoleh selama bersekolah. Kemampuan intelektual (pendidikan), fisik (biologis), dan material merupakan sumberdaya yang dapat digunakan untuk memecahkan permasalahan keluarga (Friedman 1998).

Berdasarkan hasil uji regresi, status pekerjaan ibu rumah tangga tidak berpengaruh secara signifikan terhadap cara yang digunakannya untuk dapat keluar dari masalah keuangan. Keterlibatan istri dalam membantu suami untuk mencari tambahan pendapatan dalam keluarga dapat digolongkan ke dalam aset tenaga kerja (Moser 1988). Namun, kenyataannya bekerja atau tidaknya istri dalam membantu suami tidak memiliki pengaruh terhadap jumlah cara yang ia lakukan ketika menghadapi permasalahan keuangan. Hal ini berkaitan dengan terdapatnya ibu rumah tangga yang tidak memiliki suami sehingga pendapatan keluarga tidak mengalami peningkatan yang signifikan pada keluarga dengan kepala keluarga perempuan karena uang yang digunakan terbatas pada penggunaan saat itu juga.

Hal ini berkaitan dengan kondisi keluarga besar yang sama-sama tidak mampu secara finansial sehingga meskipun seseorang tinggal bersama keluarga besar

Tabel 1. Faktor-faktor yang mempengaruhi strategi koping terhadap ketidakmampuan membeli isi ulang LPG

\begin{tabular}{lcccc}
\hline \multicolumn{1}{c}{ Variabel } & B & Beta & t & Sig. \\
\hline Usia Ibu rumah tangga (tahun) & 0,033 & 0,341 & 1,820 & $0,077^{*}$ \\
Lama Pendidikan Ibu rumah tangga (tahun) & 0,120 & 0,329 & 1,866 & $0,070^{\star}$ \\
Pekerjaan Ibu rumah tangga & $-0,047$ & $-0,022$ & $-0,144$ & 0,886 \\
(0 = tidak bekerja; 1 = bekerja) & & & & \\
Jenis Keluarga & 0,197 & 0,132 & 0,774 & 0,444 \\
(0= nuclear; 1 = extended) & & & & \\
Jumlah Anggota Keluarga (orang) & $-0,007$ & $-0,015$ & $-0,081$ & 0,936 \\
Pendapatan per Kapita Keluarga & $-0,032.10^{-2}$ & $-0,018$ & $-0,088$ & 0,931 \\
(ribu rupiah) & & & & \\
Persepsi lbu rumah tangga terhadap LPG (skor) & $-0,008$ & $-0,013$ & $-0,079$ & 0,937 \\
Sikap Ibu rumah tangga terhadap LPG (skor) & 0,146 & 0,180 & 1,176 & 0,247 \\
\hline
\end{tabular}

Keterangan : * signifikan pada taraf 0,1 
tidak menjamin ia dapat mengatasi permasalahan keuangan yang dihadapinya. Peneliti menemukan kondisi dimana keluarga besar ibu rumah tangga sebagian besar juga termasuk ke dalam kategori keluarga miskin sehingga sedikit sekali ibu rumah tangga yang memiliki keluarga dari golongan menengah ke atas. Kondisi ini menggambarkan bahwa kemiskinan di Indonesia dapat bersifat permanen karena tidak adanya keluarga besar yang mampu membantu.

Menurut Moser (1988), aset relasi rumah tangga atau keluarga (household relation asets) dapat digunakan dalam mengatasi permasalahan dalam keluarga, melalui pemanfaataan jaringan dan dukungan dari sistem keluarga besar, kelompok etnis, migrasi tenaga kerja, dan mekanisme uang kiriman (remittances). Namun, berdasarkan hasil uji regresi linear berganda, jenis keluarga juga tidak memiliki pengaruh yang signifikan terhadap kemampuan keluarga dalam menghadapi ketidakmampuan membeli LPG sehingga meskipun ibu rumah tangga berasal dari keluarga besar belum tentu ia akan menemukan banyak cara dalam mengatasi permasalahan keuangan.

Strategi koping keluarga juga tidak dipengaruhi oleh jumlah anggota keluarga. Artinya sedikit atau banyaknya jumlah anggota keluarga tidak membuat keluarga menjadi semakin sedikit atau semakin banyak memiliki kemampuan dalam menyelesaikan permasalahan keuangan di dalam keluarga. Kondisi ini kemungkinan bergantung pada sedikit atau banyaknya anggota keluarga yang termasuk ke dalam kategori usia produktif, tingkat pendidikan anggota keluarga, dan pengalaman keluarga dalam menghadapi permasalahan finansial.

Pendapatan per kapita keluarga tidak mempengaruhi sedikit atau banyaknya cara penanganan masalah keuangan keluarga meskipun menurut Moser (1988), pendapatan termasuk ke dalam aset produktif (productive asset) yang dapat digunakan oleh keluarga miskin untuk menghadapi permasalahan. Menurut Lazarus dan Folkman (1984), aset ekonomi tidak berimplikasi terhadap bagaimana keluarga dapat menggunakannya. Kondisi ibu rumah tangga yang berasal dari keluarga miskin mengakibatkan peningkatan pendapatan yang diperoleh tidak berpengaruh signifikan terhadap pemecahan masalah keluarga yang berkaitan dengan permasalahan keuangan. Selain itu, mengingat sebagian besar pekerjaan suami ialah sebagai buruh, maka pendapatan yang diperolehnya pun tidak tetap. Strategi koping yang dilakukan keluarga bergantung pada kemampuan keluarga miskin untuk mengelola aset pendapatan yang dimilikinya. Kondisi lain yang mungkin mengakibatkan pendapatan tidak berpengaruh terhadap jumlah cara yang dilakukan ialah sifat fatalisme yang dimiliki oleh keluarga miskin (Guhardja et al. 1992). Fatalisme adalah suatu sikap dimana seseorang pasrah terhadap suatu keadaan sehingga mengakibatkan ia tidak mampu dan tidak mau memikirkan cara untuk dapat keluar dari masalah. Kondisi ini mengakibatkan seseorang hanya dapat menggantungkan diri pada orang lain dan mengharapkan datangnya bantuan tanpa melalui usaha yang nyata.

Persepsi dan sikap terhadap LPG pun tidak mempengaruhi banyaknya cara yang digunakan oleh ibu rumah tangga untuk mengatasi masalah keuangannya. Hal ini menunjukkan bahwa meskipun persepsi dan sikap ibu rumah tangga baik terhadap LPG tidak menjamin ia memiliki banyak cara untuk mengatasi permasalahan keuangan yang dihadapinya. Kondisi ini berkaitan dengan mekanisme atau sistem yang diciptakan oleh pemerintah dimana seluruh masyarakat diarahkan untuk menggunakan LPG meskipun masyarakat tidak mau menerimanya. Ketika seseorang, khususnya kelompok miskin merasakan keterpaksaan dalam menerima suatu kebijakan maka ia enggan untuk memikirkan jalan keluar ketika ia dituntut untuk mengatasi permasalahan yang berkaitan dengan kebijakan tersebut. Kondisi ini mungkin terjadi karena masyarakat tidak merasa dilibatkan atau diperhatikan ketika suatu kebijakan ditetapkan oleh Pemerintah. Padahal, menurut Tittmus (1968), pengukuran ekonomis dipandang penting untuk mengukur kebijakan sosial secara objektif. Kaitannya dengan konteks ini, konsep biaya sosial dan biaya oportunitas adalah sesuatu yang penting. Ini menunjukkan bahwa seharusnya penetapan suatu kebijakan mempertimbangkan biaya sosial yang harus ditanggung baik oleh Pemerintah maupun masyarakat penerima sasaran kebijakan.

Variabel-variabel yang tidak signifikan di atas diduga juga berkaitan dengan homogenitas data (hal ini berkaitan dengan kurang beragamnya ibu rumah tangga, yakni ibu rumah tangga hanya berasal dari keluarga miskin penerima program konversi minyak tanah ke LPG). Hal ini sesuai dengan apa 
yang dikatakan oleh Sumarwan (2003) bahwa konsumen yang berada pada kelas yang sama akan menunjukkan persamaan dalam nilai-nilai yang dianut, gaya hidup, dan perilaku yang sama.

\section{KESIMPULAN DAN SARAN}

Rata-rata usia suami contoh ialah 46,22 tahun dan rata-rata usia contoh ialah 44 tahun. Berdasarkan tipe keluarga, sebanyak $60 \%$ contoh termasuk ke dalam keluarga inti. Hampir separuh contoh termasuk dalam kategori keluarga sedang. Persentase terbesar tingkat pendidikan suami $(32,65 \%)$ dan istri $(38,33 \%)$ ialah tamat SD. Proporsi ibu rumah tangga yang bekerja (45\%) lebih sedikit dibandingkan dengan contoh yang tidak bekerja (55\%). Persentase terbesar pekerjaan suami sebagai buruh (63,27\%) dan sebanyak $16,67 \%$ contoh bekerja sebagai pekerja rumah tangga. Keluarga contoh memiliki rata-rata pendapatan/ kapita/bulan sebesar Rp 106.497,00 dan rata-rata pengeluaran contoh ialah sebesar Rp 205.346,00/kapita/bulan.

Dari seluruh contoh yang menerima bantuan kompor LPG dan LPG gratis, ternyata masih terdapat 18,33\% contoh yang tidak menggunakan LPG. Masih ada sebanyak 28,33\% contoh yang memiliki persepsi yang kurang baik terhadap LPG dan $43,33 \%$ contoh yang memiliki sikap yang kurang baik terhadap LPG. Rata-rata jumlah penghematan yang dapat dilakukan oleh contoh yang beralih dari minyak tanah ke LPG ialah sebesar Rp $66.400,00$ per bulan (harga minyak sebelum program) dan Rp 202.350,00 per bulan (harga minyak setelah program). Namun, bagi contoh yang beralih dari kayu bakar ke LPG, rata-rata biaya yang dikeluarkan justru menjadi lebih besar, yakni dari Rp 10.250,00 per bulan menjadi Rp 44.700,00 per bulan. Dalam penggunaannya, lebih dari separuh pengguna LPG $(55,1 \%)$ pernah mengalami kerusakan LPG dan $91,84 \%$ pernah mengalami ketidakmampuan dalam membeli isi ulang LPG. Keberadaan keluarga dekat, saudara, tetangga, dan alternatif bahan bakar selain LPG berperan dalam mengatasi ketidakmampuan contoh dalam membeli isi ulang LPG.

Pendapatan per kapita keluarga memiliki hubungan yang positif dengan persepsi dan sikap contoh. Namun, lama pendidikan hanya berhubungan positif dengan sikap contoh. Usia dan lama pendidikan contoh berpengaruh terhadap strategi koping contoh. Persepsi dan sikap memiliki peran yang penting dalam membentuk perilaku keluarga dalam menggunakan LPG.

Hasil penelitian menunjukkan bahwa: (1) masih terdapat sebanyak $18,33 \%$ contoh yang tidak menggunakan LPG saat ini dikarenakan berbagai macam alasan, diantaranya tidak mau menggunakan, takut, mahalnya harga LPG, dan menjual tabung LPG. Oleh karena itu, penyuluhan mengenai bagaimana cara menggunakan LPG yang baik, bukan hanya sekedar informasi bahwa LPG lebih aman, bersih, hemat, dan ramah lingkungan sangat diperlukan; (2) masih terdapat contoh yang merasakan bahwa LPG tidak aman untuk digunakan dan masih merasa keterpaksaan dalam menggunakan LPG sehingga perlu tersedia LPG dan perangkatnya dengan jaminan keamanan yang tinggi berdasarkan Standar Nasional Indonesia (SNI); (3) LPG tidak memiliki pelayanan pascapenjualan yang baik, untuk itu layanan pascapenjualan LPG bagi masyarakat mutlak diperlukan bahkan di masing-masing RW; (4) hampir seluruh contoh yang menggunakan LPG pernah mengalami ketidakmampuan membeli LPG dikarenakan masalah keuangan. Berdasarkan hal ini, hendaknya masing-masing keluarga dapat meningkatkan kemampuannya dalam mengelola manajemen sumberdaya keluarganya masing-masing dengan cara menabung sedikit demi sedikit untuk mempersiapkan dana pembelian isi ulang LPG; (5) pemerintah diharapkan dapat melakukan penyuluhan mengenai bagaimana cara menggunakan LPG yang baik sangat diperlukan agar masyarakat merasa aman saat menggunakan LPG, menyediakan LPG dan perangkatnya dengan jaminan keamanan yang tinggi berdasarkan Standar Nasional Indonesia (SNI), dan memformulasikan program penanggulangan kemiskinan yang diintegrasikan dengan program konversi BBM.

\section{DAFTAR PUSTAKA}

Agustina H. 2006. Coping Strategy pada Keluarga Miskin Penerima Subsidi Langsung Tunai (SLT) BBM dalam Pemenuhan Kebutuhan Hidup dan Tingkat Kepuasan di Kota dan Kabupaten Bogor. [Skripsi]. Bogor: Fakultas Pertanian, Institut Pertanian Bogor. 
[Anonim]. 2008a. Konversi Minyak Tanah ke LPG. www.ariodesign.blogspot.com. [6 Mei 2009]

[Anonim]. 2008b. Konversi Minyak Tanah ke Gas Panen Masalah: Pengguna Gas 12 Kg Ikut Konsumsi $3 \mathrm{Kg}$. www.radarbogor.co.id. [8 September 2008]

[BPS] Badan Pusat Statistik. 2009. Berita Resmi Statistik No.37/07.Th.XI. www.bps.go.id. [September 2009]

Dinas Kesehatan. 2008. Kriteria Kemiskinan. www.dinkes.go.id. [Maret 2009]

Friedman. 1998. Family Nursing: Theory and Practice. $3^{\text {rd }}$ edition. California: Appleton \& Lange.

Furi AE. 2006. Persepsi, Tingkat Stres, dan Strategi Koping Ibu pada Keluarga Miskin Penerima Bantuan Langsung Tunai (BLT) terhadap Kenaikan Harga BBM. [Skripsi]. Bogor : Fakultas Pertanian, Institut Pertanian Bogor.

Goldsmith AB. 1996. Resource Management for Individual and Families. USA: West Publishing Company.

Guhardja S, Puspitawati H, Hartoyo, \& Martianto DH. 1992. Diktat Manajemen Sumberdaya Keluarga. Bogor: Fakutas Pertanian, Institut Pertanian Bogor.

Kotler P. 2000. Marketing Management. Millenium Editor. New Jersey: Prentice Hall.

Lazarus RS, Folkman S. 1984. Stress, Appraisal and Coping. New York: Springer Publishing Company.

Lionberger HF. 1960. Adoption of New Ideas and Practices. New York: Iowa State University Press.

LIPI. 2008. DPR Minta Pemerintah Revisi Data Warga Miskin. www.vhrmedia.com. [3 Mei 2008]

Moser. 1988. Coping Strategies: Konsepsi dan Dimensi. www.policy.hu/suharto/modul.com. [5 Juni 2009]

Remi SS. 2008. Pembangunan Berkelanjutan Bidang Ekonomi: Implikasi Proyeksi Penduduk Indonesia Tahun 2000-2025 terhadap Pembangunan Berkelanjutan Bidang Ekonomi. www.pustaka.bkkbn.go.id. [28 november 2008]

Rogers EM, Shoemaker FF. 1971. Communication of Innovation: A Cross Cultural Aprroach. New York: The Free Press.

Sumarwan U. 2003. Perilaku Konsumen: Teori dan Penerapannya dalam Pemasaran. Jakarta: Penerbit Ghalia.
Van Den Ban AW, Hawkins HS. 1996. Agricultural Extension. $2^{\text {nd }}$ Edition. New York: John Wiley and Son, Inc.

\footnotetext{
Korespondensi :

Telp : +62-251 8629227

Email : ekawulidalatifah@yahoo.com
} 